University for Business and Technology in Kosovo

UBT Knowledge Center

UBT International Conference

2015 UBT International Conference

Nov 7th, 9:00 AM - 5:00 PM

\title{
Boosting growth through intra-regional cooperation: Macedonia and Albania
}

Jasminka Varnalieva

International Balkan University, j.varnalieva@yahoo.com

Nehat Ramadani

University for Business and Technology, nehat.ramadani@ubt-uni.net

Follow this and additional works at: https://knowledgecenter.ubt-uni.net/conference

Part of the Business Commons

\section{Recommended Citation}

Varnalieva, Jasminka and Ramadani, Nehat, "Boosting growth through intra-regional cooperation: Macedonia and Albania" (2015). UBT International Conference. 32.

https://knowledgecenter.ubt-uni.net/conference/2015/all-events/32

This Event is brought to you for free and open access by the Publication and Journals at UBT Knowledge Center. It has been accepted for inclusion in UBT International Conference by an authorized administrator of UBT Knowledge Center. For more information, please contact knowledge.center@ubt-uni.net. 


\title{
Boosting growth through intra-regional cooperation: Macedonia and Albania
}

\author{
Jasminka Varnalieva ${ }^{1}$, Nehat Ramadani ${ }^{2}$ \\ ${ }^{1}$ International Balkan University, Skopje \\ ${ }^{2}$ UBT - Higher Education Institute, Pristina \\ j.varnalieva@yahoo.com ${ }^{1}$,nehat.ramadani@ubt-uni.net ${ }^{2}$
}

\begin{abstract}
The purpose of this paper is to explore the status of economic cooperation among countries in the South East Europe (SEE) with particular attention on the cooperation between Macedonia and Albania. In line with the SEE 2020 Strategy adopted by the EU aspiring countries in 2013, increased intra-regional cooperation among the countries should be used as a preparation for a smooth and faster European and Euro-Atlantic integration. This paper provides an in-depth analysis and statistics of the overall economic cooperation, trade patterns and capital movement among the countries and identifies major obstacles for increased cooperation that could result in higher economic growth rates. The paper concludes that while the cooperation among countries of former Yugoslavia is stronger, the level of cooperation between Macedonia and Albania is still very low and could be significantly increased provided certain policy instruments are implemented.
\end{abstract}

Key words: trade, cooperation, growth

\section{Introduction}

South East Europe region has made significant improvements in the last two decades, however, a number of challenges still remain for the region to come closer to the EU averages. The region managed to exit the crisis; however, the growth rates remain marginal, fluctuating between 1 and 2 percent, which is insufficient to address the needs for reindustrialization, increased labour force participation and reduction of extremely high unemployment rates. In addition to addressing these challenges through prudent macroeconomic policies, countries in the region need to embark upon deep strategic reforms addressing structural challenges in improving productivity and competitiveness, including in the areas of the investment climate, the labor market, and the public sector. In order to accelerate and improve growth, governments of SEE countries decided to take additional measures to move faster and better by joining forces and increasing regional collaboration. To that end, during the South East Europe Ministerial Conference held in Paris on 23-24 November 2011, ministers and high ranking officials from SEE endorsed a common regional vision to support continued economic reforms. This vision was translated into a specific South East Europe 2020 Strategy - Jobs and Prosperity in a European Perspective, adopted at a conference of ministers held in Sarajevo on 21 November 2013. The goal of the SEE 2020 Strategy is to improve living conditions in the region and enhance competitiveness and development, closely following the vision of the EU strategy Europe 2020. The Strategy contains eleven specific targets covering the 5 pillars of integrated, smart, sustainable and inclusive growth and good governance for growth.

\section{Recent Developments}

Macedonia and Albania are upper middle income countries that went through a long transition process to market economy and introduced a number of reforms aimed at improving business environment and attracting foreign investors in order to boost economic growth. National development programs of both countries have been built around very similar priorities, including strong economic growth, EU membership, rule of law/ fight against corruption, etc. Priority pillars in economic growth area 
are also based on the same principles, particularly related to economic development and cooperation. This could provide a good platform for better cooperation and learning from the best practices and successful policies.

Albania has made significant progress in reaching its strategic goals. It joined NATO in 2008 and submitted its application for EU membership in 2009. Albania's economy continued to grow in spite of the global economic crisis at an average growth rate of 5 percent in the years $2005-2012$. However, economic growth has stalled during the recent years and Albania's growth rate in 2013 was only 2.4 percent in 2013.

In 2005 Macedonia became candidate country on its road to EU membership. After a mild recession in 2012 (negative growth of 0.4 percent), Macedonian economy grew by 3.1 percent in 2013 with a positive prospect for growth of 3.5 percent in 2014. During the last decade, Macedonian governments put a lot of efforts and implemented very comprehensive set of reforms in order to improve the overall business environment in order to increase local investment and attract foreign investors.

Implementing reforms in the business environment is essential for growth, boosting investment and creating jobs. It is important for the local businesses as well as for the potential foreign investors. From the cross border cooperation point of view, it is also important for encouraging trade and investment in both directions.

According to the latest World Bank Doing Business report (2015), Macedonia ranks 12 in the aggregate ease of doing business indicator, leaving behind all countries in the region. With 31 regulatory reforms in total, Macedonia is $5^{\text {th }}$ best country in the world that managed to narrow the distance to frontier by 19.9 percent since 2005 . Nevertheless, there are reforms that are still needed to further improve the investment climate, such as dealing with the informal economy, which has been identified as one of the main constraints by the private sector companies in the BEEPS survey 2009. Overall, Albania introduced very few reforms in the business environment in the last years and it lags behind all countries in the region in the ease of doing business rankings. This indicates that in-depth and comprehensive reforms in all areas of business environment need to be introduced immediately in order to boost growth in the coming years. Most attention needs to be paid to the areas with lowest rankings, such as dealing with construction permits (189), getting electricity (161), paying taxes (142), registering property, and enforcing contracts (96). However, in order to maximize results, it is best to introduce in-depth reforms in all area of the business environment simultaneously.

Albania has made significant progress in reaching its strategic goals. It joined NATO in 2008 and submitted its application for EU membership in 2009. Albania's economy continued to grow in spite of the global economic crisis at an average growth rate of 5\% in the years $2005-2012$. However, economic growth has stalled during the recent years and Albania's growth rate in 2013 was only $2.4 \%$ in $2013^{20}$. Similarly, Albania has implemented reforms in business climate improvements during the last decade, most notably in improving business registration procedures through establishment of the one-stop-shop centers for business registration and licensing. However, the pace of reforms has been slow and it further slowed down recently. Albania declined in its overall ranking on the World Bank's 2015 Doing Business (DB) Indicators from the 90th (2014) to the 97th position. The only reform areas captured in the latest DB report is in paying taxes, getting credit, and trading across borders. Overall, business environment in Albania has been weak and has negatively affected its growth potential. In order to become a fully functioning market economy with good business environment, Albania will need to put additional efforts and strengthen its reforms in the coming years. Albania could use the Doing Business indicators as effective tool to design new set of policies in different areas and ultimately improve its business environment, and make the most of its resources for sustainable and smart growth.

\section{Trade liberalization}

Both Albania and Macedonia are members of World Trade Organizations (WTO) and have highly liberalized economies. They are also signatories of the Central European Free Trade Agreement (CEFTA) 2006 agreement which replaced 32 bilateral free trade agreements between the countries of

${ }^{20}$ Ministry of Finance, Government of Albania, Macro-Economic and Fiscal Framework 2013, http://www.financa.gov.al/files/userfiles/Programimi_EkonomikoFiskal/Treguesit_Makroekonom ik_ne_Vite/Treguesit_Makroekonomik-2013_shqip.pdf 
South East Europe. This agreement should simplify regional trade regime and considerably deepen regional integration by provisions on trade in services, intellectual property rights, public procurement and investment. The main objectives of the Central European Free Trade Agreement (CEFTA) 2006 are to expand trade in goods and services; foster investment by means of fair, stable and predictable rules; eliminate barriers to trade between the eight Parties to the Agreement; provide appropriate protection of intellectual property rights in accordance with international standards; and harmonize provisions on modern trade policy issues such as competition rules and state aid. The signatories of CEFTA 2006 are: Albania, Bosnia and Herzegovina, Croatia, Macedonia, Moldova, Montenegro, Serbia, and UNMIK/Kosovo. (Like Bulgaria and Romania earlier, Croatia, the latest EU member is no longer a part of CEFTA)

The objective to eliminate barriers to trade between the CEFTA Parties incorporates provisions for the elimination of Non-Tariff Barriers (NTBs), including Technical Barriers to Trade (TBTs) standards, technical regulations and conformity assessment; Sanitary and Phytosanitary (SPS) issues; and Administrative barriers to trade.

Both Albania and Macedonia actively participate in the work of the CEFTA bodies and continue to closely coordinate and align their policies with the policies and positions of the EU in the WTO. In 2012 Albania held the rotating presidency of the CEFTA.

While CEFTA objectives are structured around intraregional trade liberalization, trade between Western Balkan countries and EU are governed by specific Stabilization and Association Agreement (SAA) for each EU accession country. The most important benefits from SAAs are to be expected in the medium to long term horizon, resulting from the alignment of the legal and regulatory framework to the EU acquis. In addition, the multi-donor Trade and Transport Facilitation Program for Southeast Europe (TTFSE) managed by the World Bank, has provided significant assistance to design and effective implementation of customs reforms, removal of physical bottlenecks at border crossings and better coordination and collaboration between border control institutions in the region. As a result, efficiency in the border crossing has considerably improved, while reducing the import clearance times for trucks and reducing corruption in target sites. Overall, customs and border restrictions between SEE countries have eased in recent years, as also recorded in the Doing Business ranking for trading across borders indicators.

\section{Trade Patterns}

Macedonia and Albania had different transition paths and different problems to solve in the last 25 years; but generally speaking they both turned mostly to their traditional industries and trade partners. For Albania, the proximity and historical links to Italy created a unique opportunity in the early $90 \mathrm{~s}$ to establish very strong links and partnerships with Italian companies. For a long time, Italy has been number one investor and trade partner to Albania. Most Italian apparel and footwear companies seized the opportunity to produce good quality products with very cheap labor in Albania. This, coupled with very low shipping cost and overnight deliveries potential, led to establishment of the most apparel and footwear companies as Italian or joint venture companies. Macedonia on the other hand, has very strong and traditional links to all countries of former Yugoslavia, as well as Germany, which has been the major trading partner from EU. Albania has not been on the radar of Macedonian companies in the pre 90s period, and this tradition continued after the independence as well. At the initial stage of its transition to the market economy, Macedonia turned to its traditional partners and traditional industries, such as apparel, automotive components, ag-biz products, chemical products, etc.

Most of the products and industries in Macedonia and Albania are not complementary, but rather competing with each other. Both countries compete on the low cost (cheap labor) basis, so they neither differentiate nor innovate. In most sectors, manufacturers produce low value added products, and are very dependent on the buyers' decisions and preferences. Their negotiating power is very low. Only recently both Macedonian and Albanian manufacturers started to pay attention to the opportunities of moving up the value chain and creating more value added products. This however, is a higher risk process that requires additional investment on their side that only the most sophisticated and advanced companies are ready to accept. Having this in mind, as well as the size of local markets in both countries; increasing trade and investment relationship between the companies in the two countries remains a challenge. 
Macedonia and Albania do not have a high volume commodity exchange established. According to the preliminary data from the Statistical Office in Macedonia, the value of total exports of goods from Macedonia to Albania in 2013 was in the range of $€ 59$ million, while the import reached $€ 28.8$ million. On the export side, Macedonia's biggest export item is in the manufactured goods classified mainly by materials ( $€ 12.2$ million), crude materials, inedible, except fuels ( $€ 11.9$ million), and chemicals and related products ( $€ 11.8$ million). Macedonia has a trade surplus with Albania, importing mostly manufactured goods classified mainly by materials in the value of $€ 19.2$ million.

Table 3: Commodity exchange Macedonia and Albania2012

\begin{tabular}{|c|c|c|c|c|}
\hline \multirow[b]{2}{*}{ Item } & \multicolumn{2}{|c|}{ EXPORT } & \multicolumn{2}{|c|}{ IMPORT } \\
\hline & KG & EUR & KG & EUR \\
\hline Food and live animals & 10.694 .074 & 6.785 .139 & 3.602 .664 & 1.553 .750 \\
\hline Beverages and tobacco & 5.771 .956 & 4.201 .814 & 506.334 & 292.690 \\
\hline $\begin{array}{l}\text { Crude materials, inedible, } \\
\text { except fuels }\end{array}$ & 64.093 .341 & 9.676 .312 & 69.255 .725 & 2.119 .036 \\
\hline $\begin{array}{l}\text { Mineral fuels, lubricants and } \\
\text { related materials }\end{array}$ & 125.982 & 45.455 & 830.444 & 293.007 \\
\hline $\begin{array}{l}\text { Animal and vegetable oils, fats } \\
\text { and waxes }\end{array}$ & 8.524 .374 & 8.651 .321 & & \\
\hline $\begin{array}{l}\text { Chemicals and related } \\
\text { products, n.e.s. }\end{array}$ & 19.550 .338 & $\begin{array}{r}13.081 .54 \\
5\end{array}$ & 3.009 .060 & 1.119 .008 \\
\hline $\begin{array}{l}\text { Manufactured goods classified } \\
\text { chiefly by material }\end{array}$ & 30.462 .885 & $\begin{array}{r}10.491 .08 \\
9\end{array}$ & $\begin{array}{r}132.141 .30 \\
1\end{array}$ & $\begin{array}{r}20.813 .86 \\
3\end{array}$ \\
\hline $\begin{array}{l}\text { Machinery and transport } \\
\text { equipment }\end{array}$ & 1.346 .990 & 3.380 .021 & 377.146 & 313.287 \\
\hline $\begin{array}{l}\text { Miscellaneous manufactured } \\
\text { articles }\end{array}$ & 1.143 .054 & 2.695 .271 & 296.034 & 919.057 \\
\hline $\begin{array}{l}\text { Commodities and transactions } \\
\text { not classified elsewhere in the } \\
\text { SITC }\end{array}$ & 3.866 & 6.172 & & \\
\hline Total & $\begin{array}{r}141.716 .85 \\
9\end{array}$ & $\begin{array}{r}59.014 .13 \\
8\end{array}$ & $\begin{array}{r}210.018 .70 \\
7\end{array}$ & $\begin{array}{r}27.423 .69 \\
8\end{array}$ \\
\hline
\end{tabular}

According to the ACIT (Albanian Center for Competitiveness and International Trade) 2012 report, top five products exported from Albania to Macedonia include minerals, 46\%; basic metals, 31\%; prepared foods $9 \%$; mechanic, electric machinery, $7 \%$; and manufactured articles, $1 \%$ of total exports. On the other hand, the list of top five products imported from Macedonia to Albania includes basic metals $22 \%$; others $22 \%$; vegetable products $15 \%$; prepared food $11 \%$; and chemical industry $9 \%$ of total import.

This level of trade points out that there are still significant gaps in establishing higher volume exchange of goods and services between the two countries and increasing the level of intraregional integration. To that end, in 2012, CEFTA countries accounted for only $13 \%$ of Albanian merchandise exports and $8 \%$ of its imports. Italy still remains the single most important trading partner for Albania, getting more than half ofAlbanian merchandise exports and providing a third of its imports. For Macedonia, EU is still the biggest trading partner both for exports and imports, with Germany being the single most important partner. However, the trade relations of Macedonia with CEFTA countries are much stronger, particularly with Serbia, which is the third biggest top destination for Macedonia exports, and the fourth most important country for Macedonia imports. Below is a table illustrating Macedonia's exports and imports top 5 partners plus Albania. 
Table 4: Macedonia's Imports and Exports per Country in US\$ millions $(2011-2013)$

\begin{tabular}{lllllll}
\hline Country & Imports & Imports & Imports & Exports & Exports & Exports \\
& $\mathbf{2 0 1 1}$ & $\mathbf{2 0 1 2}$ & $\mathbf{2 0 1 3}$ & $\mathbf{2 0 1 1}$ & $\mathbf{2 0 1 2}$ & $\mathbf{2 0 1 3}$ \\
\hline Germany & 729.69 & 634.38 & 693.62 & $1,242.55$ & $1,180.75$ & $1,533.63$ \\
UK & 593.06 & 560.94 & 726.81 & 54.3 & 62.93 & 79.84 \\
Greece & 569.75 & 804.34 & 697.79 & 218.01 & 188.49 & 211.92 \\
Serbia & 498.16 & 482.72 & 522.72 & 337.48 & 298.14 & 269.73 \\
Bulgaria & 487.88 & 407.84 & 365.68 & 308.62 & 287.16 & 325.08 \\
\hline Albania & 39.46 & 35.03 & 38.16 & 87.27 & 75.66 & 78.46 \\
\hline
\end{tabular}

Source: National Bank of Macedonia, Statistics Foreign Trade per Country

The table above also provides a good example of the significance of just a few new foreign investments in Macedonia, particularly from UK, which resulted in significant changes of patterns in foreign trade both in terms of export basket of products and in trading partners.

In terms of investment across the border, the volume of FDI in both directions is very low. The inflow of FDI from Albania to Macedonia has been close to zero for most of the period in the decades of transition. The highest volume of FDI inflow from Albania was registered in 2010 amounting to $€ 37.32$ million or 1.12 percent of total FDI value. In 2012, this amount went down to $€ 28.02$ million or 0.75 percent of total FDI. Both Albania and Macedonia have registered low level of FDI, so according to the latest UNCTAD (United Nations Conference on Trade and Development) World Investment Report 2013, the stock of inward FDI reached US\$4,959 million in Macedonia and US $\$ 4,885$ million in Albania. The top five FDI investor countries in Macedonia in the period 1997 2012 are listed in the table below:

Table 5: Stock of FDI per country in Macedonia 1997-2012

\begin{tabular}{lccc}
\hline Country & $\begin{array}{l}\text { FDI per country in } € \text { FDI as a Percent of total FDI } \\
\text { millions }\end{array}$ & & \\
\hline Netherlands & 783.00 & 20.90 \\
Austria & 441.62 & 11.79 \\
Greece & 436.22 & 11.64 \\
Slovenia & 363.25 & 9.70 \\
Hungary & 346.43 & 9.25 \\
Albania & 28.02 & 0.75 \\
\hline
\end{tabular}

As for Albania, the EU also remains important source of inward investment in Albania, with Austria, Greece and Italy (in decreasing order) being the top three EU investors in the country. However, the main source of inward investment in Albania is Canada, with large investments in the field of oil production.

There is more than one reason in doing business that correlate one with another and keep the economic partnership between two countries at a low level. As a result, Macedonian companies are continuously interested to export in other neighboring countries, and are still passively observing the situation with Albania on possible improvements in doing business and general business climate that should be made. On the other hand, Albanian companies are far more proactively looking for partners in Italy, rather than for companies from Macedonia. Both countries still keep on traditional economic relations and trust built in the past.

\section{Overview of several sector specific issues}

Agriculture The agriculture sector plays an important role in Macedonia's economy through its contributions to GDP (agriculture accounts for $12 \%$ of GDP), employment, trade and the rural economy, with the country's nearly half the population living in rural areas. About $49 \%$ of the total land area is agricultural land, split evenly between cultivable land and pastures. Of the cultivated land, about $80 \%$ is used by approximately 180,000 private family farms.

Officially, almost one fifth of the working force is employed in agriculture, $14.8 \%$ of the value added products in the manufacturing sector is in the food industry and around $10 \%$ of exports is generated in agriculture. The combination of Continental and Sub-Mediterranean climate, characterized by long, 
warm summers and short, not too severe winters, and fertile soil provide generally excellent conditions for production of a range of food products.

The major contributors to exports within the food products segment, by a wide margin, are fruit and vegetables $(40.8 \%)$ and beverages $(29.0 \%)$. Within the beverages part wine is the most important component. Commendably, as of 2009, the Government has made the HACCP standard obligatory for all food producers.

The share of exports of agricultural and food products in total exports of the R. Macedonia in 2012 increased compared to 2011 (14.7\% in 2011) and accounted $15.4 \%$, while the share of imports of agricultural and food products also increased in the total export of the R. Macedonia and accounted $13.4 \%$.

The Albanian agricultural sector, which accounts for almost half of employment but only about onefifth of GDP, is limited primarily to small family operations and subsistence farming, because of a lack of modern equipment, unclear property rights, and the prevalence of small, inefficient plots of land. With $48 \%$ of total labor and $17 \%$ of GDP the agriculture sector continues to be one of the most important sectors of the Albanian economy. More than $50 \%$ of population lives in rural areas, where agriculture is the main activity.

Agriculture is one of the most determinative sectors of the Albanian national economy. Its contribution has been decreasing over years and it is estimated at $17 \%$ of GDP. According to the Census 2011 data $^{21}$, there is a shift in the composition of urban/rural population, with $54 \%$ of the population living in urban areas. The real mean growth rate of agriculture production during the last five years is estimated to about 4 percent per year. The agriculture sector suffers from the small size of farms and the fragmentation of farm land, which is a barrier to production and marketing.

The total agriculture land represents only $24 \%$ (about 695,520 ha) of the total area of the country. About 44\% (304,000ha) of the total agriculture land is in the lowland area, with relatively high productivity potential. From a total 696,000 ha agriculture land in Albania, about 562,000 ha have been privatized and still 134,000 ha or about $20 \%$ of total agriculture land are in state ownership.

Agricultural production has increased significantly in recent years. Field crop occupy about $31 \%$ of total agricultural production. Cereals, vegetables, potatoes, and wheat continue to be dominant crop. Livestock is a strategic sector in Albania. It occupies about $52 \%$ of all production of the sector. Furthermore, agro processing industry occupies about $24.4 \%$ of total estimated production from agriculture and agro-industry.

The Interim Agreement and the SAA put into contractual provision the preferences granted under the Autonomous trade measures applied since 2000, by which most Albanian agricultural products had duty and quota free access to the EU.

Albania is net importer, but the main exported products are vegetables, medical plants, eggs, mineral water, fruit juices etc.

Complementary agriculture products produced extensively could be considered as an advantage in joint promotion of selected food products to third markets in the region and EU. High quality, traditional and produced in clean environment food products could serve as a strong promotional tool for presenting the rich offer of the cross-border region.

Macedonian and Albanian agribusiness sectors share almost the same constraints, the most important being limited competitiveness of agriculture and food products mostly due to expensive and not efficient production technologies, lack of uniformed quality and lack of added value and finalization of products. Furthermore, the position of farmers in both countries needs improvements. Small size farms with small and fragmented production plots limits their development potential and cannot provide stable income to support farm holds. Migration from rural areas and unfavorable land ownership contribute to the respective problem as well. Inefficient irrigation and drainage systems, the low level of technology in use, the weak organization of farmers, low development level of agro - processing are additional challenges that need to be addressed.

Apparel Apparel manufacturing is a vital part of the Macedonian economy, providing more than 40,000 jobs or about one third of the total workforce in manufacturing sector. Its average annual exports exceed $\$ 500$ million or 22 percent of total exports. It has a tradition supplying a significant part of the former Yugoslavia market as well as many major brands and retailers throughout Europe and is well known for its quality products. For the last decade, the industry has suffered a slow decline in both exports and employment, exacerbated by the economic recession in key export markets.

${ }^{21}$ Albanian Institute of Statistics, www.instat.gov.al 
Macedonia struggles to compete in its main type of production — cut make trim (CMT) — when compared to other production locations (e.g. Asia), except in market segments where quality and lead time are as essential as price. Many companies in the Macedonian apparel industry are looking to move upstream, into fully factored, full package, private label, or own design/brand manufacturing where companies can add more value to customers and/or capture higher margins by taking on new roles in the design and production process.

Albania's apparel manufacturing sector has been very important for the country employing more than 35,000 persons and exporting more than $€ 220$ million per year, or 15.2 percent of Albania's total exports. Its main markets are Italy, Germany and Greece. The Albanian garment manufacturing history started in the 1950s, when apparel and footwear production became the country's most important industries. Apparel and textile industry in this period was producing products from fiber to garment. After 1990, most of these enterprises were privatized and many new ones were established. Apparel manufacturing has been one of the fastest growing industries in Albania, with the growth driven by a significant foreign direct investment in this sector, the availability of highly skilled workers and the entrepreneurial efforts of local business people.

In the past twenty years Albania's apparel industry has been dominated by contract business, however, a number of manufacturers started to take steps to move up the value chain to full cycle production. To do that, some of the manufacturers invested in new technologies, equipment and knowledge that allowed them to add more value to customers and realize higher margins by taking on new roles in the design and production process, including the creation of their own brands and collections.

Given that most of the customers and their sourcing agents prefer to have a range of various possibilities, they typically view the potential supplier companies in the larger regional context, so Macedonian and Albanian companies may find complementarities and synergies particularly when trying to enter new markets and attracting new clients. In this sense, there is a potential for joint participation at trade fairs, organizing B2B events, and inviting potential customers to visit matching companies from both countries. In addition, many sourcing agents for the big retail chains are interested in purchasing apparel products along with footwear products, so both apparel and footwear producers from Macedonia and Albania could organize joint trade events in different potential markets.

Tourism Macedonia and Albania, like most Balkan countries, have positioned tourism as a development priority. They face similar challenges involving overcoming the legacy of the past, and lack of investment in the sector. Tourism growth and development are inevitable throughout the region as long as peace and security, in each country and the region as a whole prevail. In the Balkans, recovery of tourism sector started in Croatia in the mid 1990s and then later spreading to Montenegro. Croatia and Montenegro are still the high performers in the region, already established themselves as tourism hotspots.

As a late entrant, Albania is lagging behind its competitors in the region whose governments have prioritized investments in supporting infrastructure and tourism planning and focused on attracting foreign operators into their domestic markets. The long term prospects of the tourism industry in Albania depend on the ability to develop modern hotel and transport infrastructure with the help of foreign investors, but also on sustainable coastal zone management and the restoration of cultural heritage attractions.

Macedonia and Albania have a different level of development of tourism and tourist related infrastructure. While Albania has put its major efforts and emphasis on the coastal tourism development, neglecting its mountains, lakes, and other natural beauties; Macedonia was only able to offer its lakes, mountains, and cultural related tourism. Given the proximity and similarity of the natural beauties of Ohrid and Prespa lake, as well as rivers and mountains, there is a big potential to prepare a joint tourism offer to attract tourists interested in different types of tourism, such as adventure tourism (including rafting, hiking, biking, and similar possibilities), cultural related tourism (visit of numerous churches, monasteries, and other archeological sites from different ages), etc.

A very positive example of regional cooperation in tourism has resulted in creating a National Geographic Website Project on Western Balkans. This collaboration resulted in the National Geographic Supplement on Western Balkans, aimed to establish the Western Balkans Geotourism Mapguide - Land of Discovery: 46 Outstanding Ways to Experience Albania, Bosnia and Herzegovina, Kosovo, Macedonia and Serbia, in partnership with the National Geographic Traveler magazine (http://www.balkansgeotourism.travel), an interactive web portal hosted by the National 
Geographic. The portal highlights the cultural, historic, and natural assets unique to the Western Balkans.

In addition to the joint tourism offer, there is a potential to increase cooperation in this area by to ensuring harmonization of standards for categorization of tourist and catering facilities and hotels. Lack of uniformed approach in categorization of tourist facilities undermines faster growth of tourism in both countries.

\section{Conclusions}

Macedonia and Albania do not have a high volume commodity exchange established. Italy still remains the single most important trading partner for Albania. For Macedonia, EU is still the biggest trading partner both for exports and imports, with Germany being the single most important partner. The inflow of FDI from Albania to Macedonia has been close to zero for most of the period in the decades of transition. The highest volume of FDI inflow from Albania was registered in 2010 amounting to $€ 37.32$ million or 1.12 percent of total FDI value.

Main constraints hampering higher level of cooperation and trade across border cooperation between Macedonia and Albania could be summarized as following: (i) there are very few information and analysis available to businesses on both sides on the opportunities to trade or invest in the other country; (ii) most of the products and industries in Macedonia and Albania are not complementary, but rather competing with each other; (iii) a number of business owners from Macedonia interested in starting a business or trade relationship with Albanian partners, stressed the problem of lack of rule of law and contracts enforcement in Albania.

In addition to the general, across the board impediments, there are sector specific issues. Macedonian and Albanian agribusiness sectors share almost the same constraints, the most important being limited competitiveness of agriculture and food products mostly due to expensive and not efficient production technologies, lack of uniformed quality and lack of added value and finalization of products.

Apparel sectors in Macedonia and Albania have been dominated by contract business and low value added products. There is a potential for joint participation at trade fairs, organizing B2B events, and inviting potential customers to visit matching companies from both countries.

Macedonia and Albania have a different level of development of tourism and tourist related infrastructure. Still, given the proximity and similarity of the natural beauties there is a big potential to prepare a joint tourism offer to attract tourists interested in different types of tourism, such as adventure tourism, cultural related tourism etc. In addition, there is a potential to increase cooperation in this area by to ensuring harmonization of standards for categorization of tourist and catering facilities and hotels.

\section{References}

1. Strategy for Industrial Policy of Republic of Macedonia 2009 -2020

http://www.economy.gov.mk/dokumenti/strategii/index.1.html

2. OECD Investment Reform Index 2010, Monitoring policies and Institutions for Direct Investment in South-East Europe

3. World Bank: Albania, Building Competitiveness in Albania, October 2009

4. World Bank, Western Balkan Integration and the EU, An Agenda for Trade and Growth, S. Kathuria,2008

5. IMF Country Report Albania No. 14/78 March 2014

http://www.imf.org/external/pubs/cat/longres.aspx?sk=41423.0

6. Albanian Institute of Statistics, www.instat.gov.al

7. National Bank of Macedonia, Statistics Foreign Trade per Country

8. UNCTAD (United Nations Conference on Trade and Development) World Investment Report 2013

9. ACIT (Albanian Center for Competitiveness and International Trade) Annual Trade Report 2012 